\title{
Fond memories: research, mentoring and networking
}

\author{
M.R. Jisnuson Svasti \\ Laboratory of Biochemistry, Chulabhorn Research Institute, Laksi, Bangkok 10210 Thailand \\ e-mail: jisnuson@cri.or.th
}

When the present Editor-in-Chief, a former student, asked me to write an Invited Editorial, I reluctantly agreed, since as former advisors, we try to do the best for our students, and hopefully our students will also do the best for us. So, this article will be about "Fond Memories: research, mentoring and networking", some of which I have recounted in two books $[1,2]$ compiled for my recent Sixth Cycle 72nd Birthday, and another for my Fifth Cycle 60th Birthday [3].

The idea of "Fond Memories" comes from the occasion when I received a Travel Fellowship from International Union of Biochemistry and (Molecular Biology), IUB(MB) in 1976, and was asked to write about it to celebrate the 50th Anniversary of IUBMB in 2005. I said that I did not remember much, because it was nearly 30 years ago, but Mary Osborne, IUBMB President, replied "Then, anything you remember must be important!" So, I wrote a short, but meaningful article [4] about why travel fellowships are important, and the special importance of this fellowship to my career. This is the spirit of the present article on "Fond Memories", namely that anything you remember after a long time must be important to you and may also have impact on the academic community.

My career in Thailand is a little unusual, since I was educated in England from the age of 6 to 24 years, so Thai still seems like a foreign language! I obtained my B.A. Hons. degree in Biochemistry at the University of Cambridge (1965-1968). Then, I was fortunate to study for my Ph.D. (1968-1972) at the MRC Laboratory of Molecular Biology (LMB). Since I was interested in proteins, I wanted to work with Fred Sanger, who won his first Nobel Prize on sequence analysis of the protein insulin in 1958. But, Fred, who was one of the most modest persons I have ever met, had already moved on to nucleic acid sequencing, and later won a second Nobel Prize for this in 1980. So, I decided to work with his colleague César Milstein, who was using protein chemistry to help understand immunoglobulin structure, and César later received the Nobel Prize in 1984 for his work on monoclonal antibodies.
Working at the LMB in those days was a very memorable experience, since LMB has won 12 Nobel Prizes in less than 60 years after its foundation. Max Perutz [5] has attributed this to 4 major factors, a) attracting and supporting the most talented young people; b) encouraging scientists to talk to each other; c) having good workshop facilities; d) lack of bureaucracy. Selecting the best young scientists and giving them the freedom to follow their dreams allowed the LMB to excel in forefront research areas. Then, to encourage interaction between scientists, a canteen with good inexpensive food was provided, where we all went three times a day and talked with other researchers at all levels and disciplines. Laboratories were not locked, so we could enter other rooms to use equipment and exchange ideas with those working there: even today, I still don't lock my office. Then, good workshop facilities are essential so that researchers can design and have equipment made for innovative methods, which allows them to be years ahead of other scientists who buy equipment from companies. Indeed, many Nobel Prizes have resulted from the development of novel techniques, such as protein and nucleic acid sequencing developed by Fred Sanger. Finally, the administrative system was made simple to allow scientists to concentrate on their research, but unfortunately, bureaucracy in Thailand continues to increase in the name of accountability, wasting time better spent doing research.

Unlike today when commercial kits are available, laboratory work then required careful design so as to optimize experiments to achieve particular objectives, and sometimes purifying reagents, such as redistilling phenyl isothiocyanate. Some laboratory work would probably be considered dangerous now, like exposure to pyridine and toluene during paper electrophoresis, using the nose to detect oxidation of dithiothreitol, and doing ${ }^{14} \mathrm{C}$ and ${ }^{35} \mathrm{~S}$ isotope experiments outside the Hot Room, because that room was so highly radioactive with carrier free ${ }^{32} \mathrm{P}$ from Fred's laboratory. My advisor, César Milstein was friendly and had good ideas, and of- 
ten spent much time evaluating the experimental results. The first year was rather difficult because techniques for sequencing peptide mixtures were not available until the development of mass spectrometric approaches in the 1980's. Fortunately, César switched me to another project, which worked well, so I published my first paper in Nature [6], relieving much of the stress.

After my graduation and return to Bangkok, César continued to help by performing amino acid analyses. I visited him several times, and he occasionally came to Bangkok, then later as a member of the Prince Mahidol Award Committee. Then on 14 February 2000, when I was visiting Cambridge, César invited Fred to join us for dinner. But since it was Valentine's Day, the good restaurants had been booked by students, celebrating their day of love. So, we were left to dine at a modest Chinese restaurant (Fig. 1a), but it was wonderful occasion to meet with my dear teachers. I have also recently had the pleasant experience of this teacherstudent relationship in the reverse direction, when my former students celebrated my 72nd Birthday (Fig. 1b).

When César died in 2002, I attended the Milstein Memorial Symposium at the LMB, where several students and postdoctoral researchers described similar thoughts, namely that "Milstein did not seem show much interest when experiments gave the expected results but got very excited when they did not". This reaction may be surprising, but all experiments are designed assuming certain concepts, so if the results are as expected, this confirms the original concepts, but if the results do not turn out as planned, then may be the original concepts were wrong, and a new paradigm needs to be discovered. I had memories of this when César saw that the Nterminal sequence of the light chains from cultured myeloma cells differed from the sequence which I determined using light chains from MOPC 21 myeloma isolated from the mouse. This difference later led to the idea that secreted proteins have a signal sequence at the $\mathrm{N}$-terminus.

After my Ph.D., I returned to Bangkok to become a staff member of the Department of Biochemistry, Faculty of Science, Mahidol University. When I joined, Jim Olson, Head of the Biochemistry Department, had already ordered peptide mapping equipment for my research. Those were exciting times, with several young staff members, returning with different expertise and trying their best to do good research, as well to teach without any prior experience. Serene Vimokesant, the next Head, who was rather more senior, helped us to get organized. Since local funding was very limited, we had to seek overseas funding, and so formed 3 research groups, Nutrition, Reproductive Biology, and Infectious Disease. This group approach helps to provide the critical mass of researchers needed to obtain grants and publish enough papers to be sustainable. In our case, researchers also had complementary expertise, so they can advise or collaborate with each other. In addition, as noted in the case of LMB, the group approach provides opportunity to discuss and share problems, ideas and possible research directions.

Since I have previously written about research during my career [7], I will omit the details here. However, my emphasis has always been on protein science and enzymology. Typically, I would have two areas of interest, the action of proteins under normal conditions and abnormalities in proteins which can cause disease, since each helps to explain the other. At Mahidol University, I joined the Reproductive Biology Group, headed by Montri Chulavatnatol, and worked on proteins and enzymes from the human male reproductive system. I have memories, although not exactly fond, of obtaining samples for these projects - and this was in 1973, when there was little discussion of the ethics of human experimentation, not just in Thailand but worldwide. Thus, samples of sperm were obtained from prisoners or volunteers, with a small fee, but for samples of human testis, heart and liver, we went to the police hospital, to choose a cadaver, which was not exactly a comfortable experience. For, protein abnormalities, I initially wanted to work on Abnormal Hemoglobins, but Sanga Pootrakul was already doing that. So, I worked on abnormalities in Glucose-6-phosphate Dehydrogenase (G6PD), which involved purifying the enzyme from red blood cells using litres of blood since levels of enzyme were low. Since donated blood was kept for blood transfusions, my collaborator Vicharn Panich provided HbsAg+ blood, which would probably have been fine, except for the one time when the lid flew off my centrifuge rotor. But Sanga died young, and I returned to Abnormal Hemoglobins and Thalassemia, later sharing the Outstanding Scientist of Thailand Award with Suthat Fucharoen.

Then, I turned to Glycosidase Enzymes, as a result of a Thai-UK collaborative program in biotechnology, but continued with Hemoglobinopathies until DNA technologies became more prevalent and peptide mapping was not required. Then, in 1987, the Chulabhorn Research Institute (CRI) was founded by H.R.H. Princess Chulabhorn to celebrate 

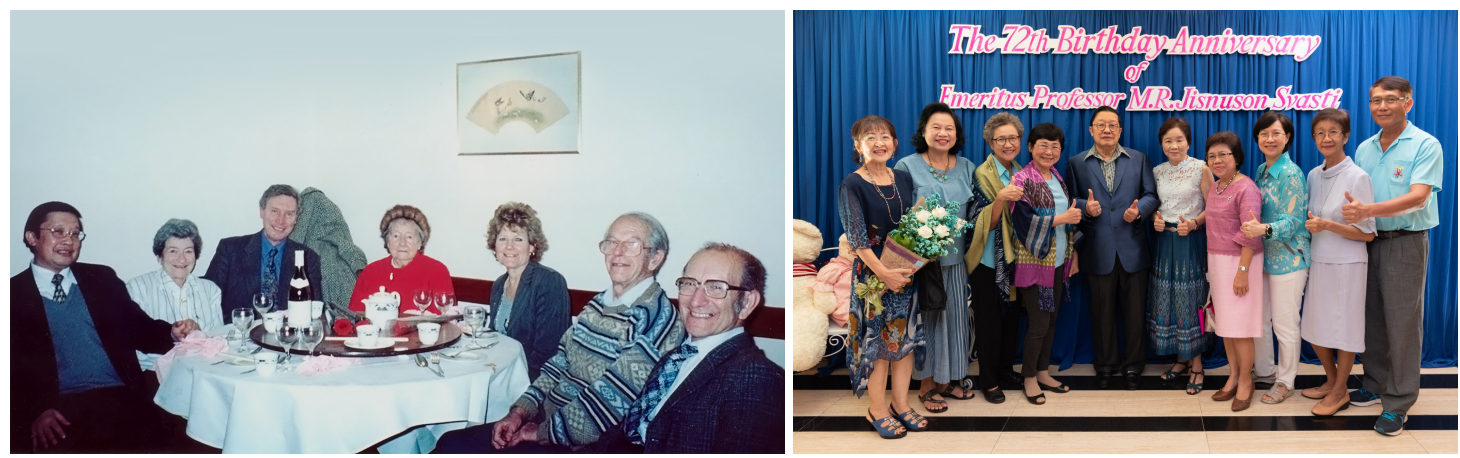

Fig. 1 The special relationship between teacher and student: (left) With my teachers, César Milstein, Frederick Sanger, and Richard Perham [2]; (right) With my former students celebrating my 72nd Birthday.

the 60th Birthday Anniversary of H.M. King Bhumibol Adulyadej, with the objective of using science and technology to improve quality of life. A fond memory came at the official opening of CRI, where H.M. Rama IX visited the posters of each Laboratory Head. When H.M. reached my poster, he asked whether I would move to CRI, to which I replied no, because I was working at Mahidol University. H.M. then asked whether I would move after I retired from Mahidol University: I don't think that any Thai person would deny His Majesty Rama IX. So here I am, still working part-time at CRI at the age of 72 , although initially before retirement, I held dual positions at Mahidol University and at the Laboratory of Biochemistry, CRI. Now, taking the theme of improving quality of life, our laboratory at CRI works mainly on diseases involving proteins, including cancer and inborn errors of metabolism, and more recently expanding to protein changes caused by pesticides.

I also received the prestigious TRF Senior Research Fellow grant, awarded to a senior researcher to mentor a team of young researchers and help them develop. My grant on "Protein Structure and Molecular Enzymology" in 2001-2007 had 18 researchers from 10 universities in Thailand. Mentorship is rather difficult to define, but a mentor is essentially an academic father/mother who helps a young researcher develop, do research of quality and advance in his/her career. This may include helping the advisee to develop expertise and laboratory skills, evaluate results and their implications, as well as to adjust research direction if needed. In the case of postdoctoral researchers, it may also involve help in setting up a laboratory, applying for grants, contacting other researchers, and assistance in writing papers. Essentially, the mentor provides an example of how a scientist can succeed under local conditions, such as how to solve problems and how to behave. The advisee learns by adsorbing the attitudes, thoughts and ideas of the mentor. So, it is a two-way process between mentor and advisee, based on truth, mutual respect and trust. Indeed, a suitable advisee may become the academic heir of mentor.

I also taught, but teaching load was not heavy, with only a few lectures in Thai for undergraduate courses in health sciences. Overall emphasis was on M.Sc. and Ph.D. degree programs in biochemistry, which were heavily research orientated and fortunately taught in English. As a result, our work mainly involved mentorship of graduate students and hands-on-research, which I enjoyed. Many of our graduate students became staff at several universities in Thailand, both in Bangkok and in the provinces, so I still have good connections with former alumni throughout the country, although some are now retired. In the early days, Bhinyo Panijpan and I also started biochemical education activities to provide examples of work, that required little or no equipment, but could be published in international journals. This included devising simple student laboratories requiring little equipment, explanations of novel techniques, textbook errors, surveys of course content at Thai universities, which have been compiled in my academic book [1]. I also co-authored one of the first biochemistry textbooks written in Thai and helped make audio-visual teaching materials.

I also have fond memories of working for national societies and foundations, as well as regional associations and international unions. The Science Society of Thailand (SST) has been like a family to me, which I joined upon returning to Thailand. First, I served as Editor of the Journal of the Science Society of Thailand (JSST) between 1985-1987, and 
later as Editor of ScienceAsia, the new name, between 2001-2007. I wrote several Editorials, which are included in my academic book [1]. I also published the research of my first M.Sc. student in the first issue of the journal in 1975 [8], since JSST was striving to be an international journal and needed good research papers. Overall, I have probably published some 6 research papers, 2 reviews, and 11 Editorials in JSST/ScienceAsia, out of a total of some 200 research papers and 30 academic articles in my career. I also served as Chairman of the Biochemistry and Molecular Biology Section (BMB) (1986-1987), which represents all biochemists in Thailand and continue to engage in its activities. Lastly, I served as President of SST (2008-2011), becoming involved in activities for school children, such as the Thai Science Camp, as well as activities promoting public awareness of science, in addition to academic activities.

I have also enjoyed interacting with overseas organizations, especially the Federation of Asian and Oceanian Biochemists (and Molecular Biologists) or FAOB (MB), a regional association affiliated with IUBMB. This began when I received a Travel Fellowship to attend the IUB Congress in Hamburg, 1976, as mentioned earlier [4], and acted as the "Recorder" of the FAOB Council Meeting, which helped to revitalize FAOB after a slow start. That meeting made me feel involved with FAOB and was followed by a memorable meeting at the Bangalore Congress in 1980, where I was selected to be Treasurer (1980-1986), without being aware of any such plan. I was later elected President (1990 1992), where I had the satisfaction of registering FAOB as a tax-exempt organization in Australia, starting membership scheme for companies, and initiating endowments. Recently, FAOBMB appointed a new archivist, and I was able to provide many documents, which I had kept because FAOBMB has been important to my life, since it provided me with the opportunity to help biochemists and develop biochemistry in the region.

Later, as protein science grew in Thailand, I helped to start the Protein Society of Thailand (PST) in 2006 and have been its President from the start. PST is also a member of regional associations, so I have served the Asia Pacific Protein Association (APPA) as President (2017-2018) and the Asian Oceanian Human Proteome Organization (AOHUPO) as Council Member (2004-2016). However, neither of these organizations has become formally registered, possibly because not all countries in the region have proteomics and/or protein societies. I have also served as a Governing Council Member of the Asia-Pacific International Molecular Biology Network (A-IMBN) since its foundation in 1998, but this network is based on individuals rather than societies in each country, so is more difficult to sustain. So, my experience has shown that not all international or regional academic organizations can achieve continuity and have strong impact.

I have tried to minimize my work in administration but could not completely avoid it. So, I became Chairman of the Department of Biochemistry (1980-1984), Deputy-Dean of the Faculty of Science (1996-1997), Vice-President for International Relations (1997-1999), and Dean of the Faculty of Graduate Studies (2004-2007). However, I have always continued doing research, because I believe teaching and research are the opposite sides of the coin of knowledge [9], so academic staff should continue to do research. Then, as a teacher, the success of a former student or someone we have mentored brings fond memories and happiness. These successes have included advisees who have become university president, faculty dean, executive of regional organizations, and winners of outstanding research awards. Indeed, the success of an advisee is the success of the advisor/mentor, which makes me proud and happy. However, failure can later lead to success, as in the case of a graduate student from Africa, whom I had to retire because he could not pass the examinations: 2-3 years later, he sent me a New Year card from the Middle East, in which he wrote "In the land of the blind, the one eyed man is a king". This card brought a smile to my face to see that he has discovered himself and found a role in life that satisfies him.

Finally, another fond but unusual memory came when I reluctantly agreed to act as Chief Rapporteur to summarize the 9th Conference of the Asian Federation of Mental Retardation (AFMR) on "Improving Quality of Life for Mentally Retarded" in November 1989 [3]. Since I knew little about the subject, I read all the Abstracts and attended all the lectures that I could. Most importantly, I was introduced to Father Brendan O'Connell, an American priest from Taiwan, whose wisdom and empathy helped me to appreciate this field. Then in delivering, my Summary [7], I began by discussing what quality of life means to me, followed by a summary of the issues and recommendations raised at the conference. However, I realized that an important issue of mentally retarded (or indeed other physically disabled persons) was acceptance by the community, so I concluded with this rather emotional summary: 
"The mentally regarded person is part of the spectrum of the diversity of mankind. Unknowingly, his birth brings great anguish and suffering to his parents, but his innocence is able to bring out the best in them and all who work with him. He has a limited potential that we should be realistic about. We should help him reach his potential and take his place alongside us. As a human being, he has dignity, so what we do for him, we do in the name of justice and not in the name of charity." [10]

In conclusion, this has been an unusual Invited Editorial, but all of us have fond memories, which often reflect the important events in our lives. I have selected a few memories that have had impact on my career as an academic. As a Ph.D. student, I was fortunate to have a great scientist as an advisor, as well as to work at a world class laboratory, where the interaction of minds leads to understanding, novel ideas, and important discoveries. Returning to Bangkok, I was able to continue my interests in protein science until the present day. Then, as a teacher, I have been proud of many former students. So, I believe that the friendly relationship between teachers/mentors and their students/advisees is an important foundation for academic success. Some memories also relate to changes in career path, for example, the decision to serve as FAOB Treasurer, which led me deeper into activities as President. This made me enjoy involvement with societies, including SST, BMB, and ScienceAsia, as well as founding PST as a result of my interest in protein science. All in all, I have been happy with my career as academic, doing research, contributing to the scientific community and mentoring the young.
Most of all, some memories can even transform you, but sometimes to really appreciate them, you need to:

"Open your eyes, so you can see that others do not see, Open your ears, so you can hear what people say, and what they don't say,

Open your mind, so you can understand, and

Open your heart, so you can feel what others feel." $[1,2]$

\section{REFERENCES}

1. Svasti M.R. J (2019) On the 72nd Birthday Anniversary of M.R. Jisnuson Svasti, September 2019, Sigma Graphics Co. Ltd., Bangkok.

2. Svasti M.R. J (2019) Harmony of Life, Parkpim Printing Co., Bangkok.

3. Svasti M.R. J (2007) Melody of Life, Amarin Printing and Publishing PLC, Bangkok.

4. Svasti J (2005) My experience as an IUB travel fellow. IUBMB Life 57, ID 255.

5. Perutz MF (1997) The Medical Research Council Laboratory of Molecular Biology, NobelPrize.org, Nobel Media AB 2020.

6. Svasti J, Milstein C (1970) Variability of interchain binding of immunoglobulins: inter-chain bridges of mouse IgG1. Nature (Lond) 228, 933-935.

7. Svasti J (2018) Fifty years of protein research: personal experience. ScienceAsia 44S1, 28-38.

8. Svasti J, Viriyachai S (1975) The purification of lactate dehydrogenase isozymes LDH-A4, LDH-B4 and LDH-C4 from human tissues. J Sci Soc Thailand 1, 57-71.

9. Svasti J (2006) Teaching and research: opposite faces of the same coin? ScienceAsia 32, 333-335.

10. Svasti J (1989) Improved quality of life for the mentally retarded. $J$ Pediat Soc Thailand 28, 993-998. 